\title{
Knowledge Management and Decennial Growth of a Private Sector Bank - A Case Study of ICICI Bank
}

\author{
D. Sudha Rani ${ }^{1}$ K. Rama Mohana Rao ${ }^{2}$ And P. Vijay Kumar ${ }^{3}$ \\ ${ }^{1}$ P-4, Shivajipalem quarters, Pedawaltair, Visakhapatnam - 530017, India, \\ ${ }^{2}$ Department of Commerce \& Management, Andhra University, Visakhapatnam, 530003, India, \\ ${ }^{3}$ School of Management Studies, JNTU Kakinada, Kakinada, 533003, India,
}

\begin{abstract}
All over the globe the banking sector has witnessed a drastic change during the last decade. After liberalization, globalization and privatization initiatives of the government of India the scenario in banking sector has been changed. The private sector banks have strengthened significantly through sound financial health by adopting best methodologies and practices. The performance of private sector banks has influenced the growth of Indian economy and financial institutions. During the period of 2002-12 the banking sector in India has undergone different phases of global economic crisis. This period includes the pre crisis time, the crisis time and post crisis period. But the private sector bank which adopted knowledge management strategy from the beginning of this decade has not much affected by the global crisis in its performance and growth. Hence, in this paper to understand the implementation strategy of knowledge management initiatives and its impact, we study the performance of the largest private sector bank in India (ICICI bank) by analyzing the growth and trends of various performance parameters namely, 1) deposits, 2) investments, 3) assets, 4) expenditure, 5) income, 6) profit, and 7) other business related parameters. It is observed that in ICICI bank all these parameters have recorded an increasing trend during the period 2002-12 except in the period 2008-10. In the year 2008-10 due to world economic crisis the ICICI bank also suffered with a negative compound growth in some parameters. But with respect to other parameter the bank recorded a significant growth. However, in all parameters the bank is again performing well with positive growth after 2010 onwards.
\end{abstract}

Key words: Knowledge management, Decennial growth, performance parameters, Private sector banks, ICICI Bank.

\section{Introduction}

The Indian commercial banks can be classified into two categories namely, public sector banks and private sector banks. There is a drastic change in both private and public sector banks due to the modern information and communication technologies and their applications. By adopting effective knowledge management strategies either directly or indirectly the banks are achieving their goals and objectives. Among the Indian commercial banks the new private banks and state bank of India are performing better than the other banks. These banks are in the forefront for providing better service options and benefits to the customers. The new technology drivers such as IT and ICT made the banking business more challenging and encouraged to bring reforms in several areas such as e- banking, ATM, EDI, EFI, online banking Tele banking. For effective implementation of all these initiatives one major consideration is Knowledge management (Khalid Alrawi et. al (2009)). Bhogaraju (2005) mentioned both knowledge sharing and reuse is to be encouraged in all organisations to achieve the sustained strategic commitment of employees.

To a large extent for many banks the Knowledge management capabilities dictates their long term prosperity. The analytical thinking and utilisation of knowledge within the organisation create a competitive edge over others. There are several instances where knowledge management brought success in their performance. World Bank, Bank of Montreal, Reserve bank of India and Deutsche bank are some examples to mention the success of knowledge management in banking industry (Samir Baruah (2008), Chamindra Chiran Jayasundara (2008), Suvarchala M.B. (2013), Sudharani et al (2013)). Yogeswaran and Selvaraj (2011) studied the knowledge centric human resource management and stated that knowledge management has a significant role in bank's success or failure. They compared the human resource practices in ICICI bank and SBI. Rita Yi Man Li (2012) reviewed the knowledge management through sharing, creating and disseminating knowledge in developing countries' banking industry and stated ICICI bank is the only bank which is implementing knowledge management in a structured manner and more professionally. In India the first commercial bank which adopted knowledge management as a key driver for its professional development is ICICI bank.

The success of ICICI bank is due to its professional management and adopting the modern methods of best methodologies and practices. One of the most important initiatives the bank adopted in 2002 is the implementation of Knowledge management strategy. As a result of this initiative the bank has established as 
one of the best private sector bank in India (Anurag.B.Singh and Priyanka Tandon (2012)). The development, performance and growth of the bank during the last ten years is needed for all stake holders of the banking sector to understand the effective drivers of banking sector in India due to privatization and knowledge management implementation. Hence, in this paper we discuss the implementation strategy of Knowledge Management and its impact on development and growth of a private sector bank namely, ICICI Bank over a decade. The experiences and issues of knowledge management in ICICI bank provide insights and ideas for implementing best practices in other commercial banks.

\section{ICICI Bank}

ICICI bank is the largest private sector bank and the second largest bank in India by assets and third largest bank by market capitalization. It provides spectra of banking services to retail and corporate customers. It is an Indian multinational commercial bank. Its head quarters are at Mumbai having operations in 19 countries including U.S.A, Singapore, Bahrain, Hongkong, Srilanka, Qatar and Dubai. It has subsidiaries in United Kingdom, Russia, Canada, Belgium and Germany. As on 2013 march $31^{\text {st }}$, it has 3350 branches and 10486 ATM's in India (ICICI bank $19^{\text {th }}$ annual report and accounts 2012-2013). The Industrial Credit and Investment Corporation of India an Indian financial institute started in 1954 was the origin for ICICI bank. In 1998 ICICI bank launched its internet banking operations. In 2000, it is the first Indian bank being listed on New York stock exchange. In 2010, it has acquired bank of Rajasthan. It is the first Indian bank that helped in setting the CIBIL in 2000. It has taken several initiatives in implementing programs for social development under corporate social responsibility (ICICI Bank bulletin 2012).

\section{Knowledge Management in ICICI Bank}

ICICI bank has initiated knowledge management strategy in the year 2000. Since then it became an important operational initiative for gaining success in its development and expansion. The knowledge management strategy also became robust in the bank through its flexibility, innovative methods and effective scientific tools, which are well accepted by the employees of the bank. When the knowledge management strategy was initiated the bank was having only just 1200 staff. Because of the key important role adopted by knowledge management group, the bank has become the second largest bank in India today.

The knowledge management initiative was started when the bank's growth was ignited with professional management methodologies. The bank adopted a strategy of linking technology with infrastructure through corporate intranet, ICICI universe which provide a platform for employee to habituate towards technological utilizations. Employees were provided computer training and access to the personal files in HR through intranet. These activities have encouraged the employees and to get acquainted with web based applications and to overcome any fear towards technology. It also created interest in employees of the bank to visit the portal more frequently.

The first initiative of the bank towards the knowledge management is floating the idea of knowledge management as a simple routine activity but not as a project. This is created by providing the staff facility of intranet through which they can participate in collaborative activities and shares their knowledge with discussions and contributing towards knowledge repository. In 2002 the ICICI bank had a reverse merger with its parent organization with ICICI. Then the knowledge management team has restructured its strategy to suit for the new corporate. The initial issues for the knowledge management team in ICICI bank were: bring interaction and collaboration among the vast pool of employees, sharing of business information related to clients deals and ideas among the employees, change management through effective communication channels, addressing the problem of knowledge pool iteration and training and skill development of employees towards knowledge management. These issues were well tackled by creating zeal among staff towards acquiring, sharing and disseminating knowledge. The creation of the knowledge management culture has educated and made the employees to think positively and professionally towards external competitive challenges of the business and to stimulate for getting new thoughts, ideas and ways of working.

The bank has developed the wise guy in the knowledge management intranet portal which was easily accessible from the main staff portal for capturing and disseminating knowledge of its employees. To develop the wise guy a group of people from different departments such as HR, technology research and knowledge management were put together and given the responsibility. Eventually it became a part of bank's intranet. All interested people were given login ids, passwords by the system administrator. To generate the awareness of wise guy mails were sent to all the employees and banners were put on the intranet site. It was introduced to create the culture of knowledge sharing and provided a frame work to bring together the virtual team.

The both explicit and tacit knowledge in ICICI bank was captured and compiled. The facet knowledge in the organization was procured by motivating the employees to share and record their experiences, thinking competitive, commitment and deed. To sustain interest of employees towards knowledge management the employee contribution in the wise guy were acknowledged. The confidential sections in the wise guy are 
maintained by the administrator. The privacy and security of confidential information for all sections were well protected. The contents of the wise guy portal are discussions, queries, edited contributions, books, training calendar, vendor, internal and external reports events, captured of line lectures and presentations. In the wise guy portal the knowledge events were organized from time to time and employees will interact with top management are experts. The web portal with a treasure of knowledge is providing answers, standard templates, formats, agreements and guidelines.

The importance of scalability of the knowledge management portal cannot be under estimated. It recorded one million logins in 2004, just in 2 years after the site was redesigned. The number of staff using the knowledge management portal has increased abnormally on an average about 10,000 users visit the site daily. More than 50 divisions in ICICI bank contribute and publish their knowledge in the knowledge management portal. There are more than 25,000 individual items and about 1,500 daily searches for information. There are about 10,000 interacts to posting in the portal. These interactive sections include discussion forums, book reviews and query boards, the rewards and recognition schemes, single point lessons, etc.

The document management system of provides a structural view of its content. It provides the personalized content access to the specified users. The collaboration was improved through theme specific interfaces. It contains centralized and distributed publishing capabilities. The business groups can create their own mini domain through data driven approaches. The sub modules contain a variety of sections.

The major contributions of knowledge management in ICICI bank are: It helped the bank to create a culture of knowledge through creation of a common knowledge store in the bank. The staff are identified in house expertise and sources of knowledge through trouble shooting. It developed a sense of belonging and ownership among staff and improved commitment. It provided good decision making ability to the employees. It created a means and ways for up gradation of employee skills. It provided an opportunity for all employees to interact with other departmental staff and improve other departmental cooperation. It provided a platform for employee recognition for contribution of knowledge to the bank repository. In addition to these benefits the company enjoyed a lot of intangible benefits through the knowledge management.

The knowledge management program in the ICICI bank was not taken up as a top management directive but it is a culture of employees working with the knowledge management program. The employees associated with the knowledge management program realized the value and benefits they get and proud to become a knowledge management associate in the bank. The personnel associated with knowledge management are thinking that their work place is not mere physical location, but it is a place for knowledge improvement and professional development. The satisfied users of knowledge management support the system through system handling behaviour such as knowledge sharing, self help, and collaboration.

In addition to the knowledge portal the ICICI bank had initiated several other knowledge management practices. They are wise Wednesday, brown bag, daily dose, learning matrices and the corporate information bank. As some of the senior people were hesitant to share their knowledge through the web portal, the knowledge management team has invited those people to share their facet knowledge through an informed manner. These people were given importance and made them to share their experiences and ideas through informal gatherings. The initiative is known as wise Wednesday and the bank has conducted more than 400 knowledge leader series in various topics covering finance internal business leadership and strategy during the last 10 years. This initiative has helped the bank to popularize knowledge management.

Another initiative of knowledge management in the bank is creation of zeal towards learning across the groups. The employees in the corporate offices are invited to bring a presentation on a particular subject along with their lunch to the web conferences and live web casts. The users of knowledge management can participate from any location and share their ideas, with these notable individuals. This has encouraged the staff to get self motivation towards knowledge creation and sharing. Another important initiative of knowledge management introduced in the bank is corporate learning. In this strategy the ability of the employee to learn from teammates across the groups is encouraged. This has created a learning environment in the bank through push mechanism and collaboration. This initiative is known as the daily does which present the summary of items which are new in the banking business and the portal. This daily does includes opinions, feature headlines, poles, customer appreciations, happenings, newsletters and other updates of the events. By delivering this information directly to the mail box the knowledge management team is able to disseminate and distribute knowledge to the bank employees in the morning itself. This became an important part of their work for all the employees associated with the knowledge management. This daily does lend high profile to the knowledge management initiatives.

Another important initiative of knowledge management in the bank is news room, in which the daily news headlines are published on the internal space of the bank. All employees are able to refresh their knowledge through the news letter published by business group media releases which provide the information on their computers. The one page reviews on several topics, various expert opinions, on banking problem articles, training modules and online research tools are provided through knowledge mailers. The knowledge management team has created a query board which includes a repository of questions which were frequently 
asked by their employees. This also includes the queries and answers related to the banking operations. Through this query board the knowledge management team established an online general discussions forum in which the employees can share their knowledge on different domains through intranet. The query board serves as the fastest and reliable sources for doubt clarification or work rule procedures, policies, technical know - how and many more related to the working problems. In addition to these the knowledge management team offers a general discussion forum on the intranet. So that the employees can share their ideas and suggestions regarding business finance economy related topics and highly related operations of the bank.

With all these knowledge management initiatives the employees are able to create organizations intellectual capital. In ICICI bank knowledge management is adopted not just like a technique or practice for the organization development and growth, but it is implemented through its philosophy of change management in the people, processes for quality and continual improvement. Every employee associated with the knowledge management in the bank felt that it is an opportunity for them to develop themselves to excel in their day to day activity. The culture in the bank has changed and it became a key to encourage the employee participation for knowledge capital. The employees are well rewarded and recognized in the bank and are provided with Kpoints for their contribution in knowledge through writing the articles, uploading the documents, posting the queries, responding the queries, initiating the discussions, rating the discussions etc.,. The people who spoke in the knowledge leader series are given certificates signed by the CEO of their bank. The bank is having a well structured knowledge management strategy and it is reviewed and monitored by top management periodically (Deepu Prabhu (2006)).

\section{Growth and Development of ICICI Bank}

The growth and performance of a bank is highly influenced by the best methodologies and practices adopted. Since inception, the economic policies of the ICICI bank are sound. There is a significant growth in all operational parameters of the ICICI bank during the last decade. The adoption of internet banking, tele banking, etc., has provided ample opportunity for the bank to improve its performance. After the liberalization policy in early 1990, the government of India has licensed private sector banks. During that period the ICICI bank was established as Tech - savvy bank. The rapid growth in the economy of India up to 2006 - 07 has revitalized the banking sector in India and the ICICI bank has a strong contribution for Indian commercial banking sector.

To understand the growth and trends of ICICI bank the data on the performance parameters such as deposits, current deposits, savings bank deposits, CASA deposits, share of CASA percentage, advances, investments, working funds, total expenses, interest expenses, staff expenses, other expenses, total income, interest income, other income, gross profit, provisions and contingences, net profit, gross NPA, net NPA, staff strength, number of branches, the ratio of non - interest of income to total income, the ratio of spread to average working fund, the ratio of establishment expenses to average working fund, the ratio of other expenses to average working fund, the ratio of gross profit to average working fund, return on assets, return on average assets, total business, business per employee, business per branch, net profit per employee, gross profit per employee, gross profit per branch, net profit per branch is collected from ICICI annual reports, RBI reports from the year 2002 to 2012 along with their annual compound growth rates. For comprehensive analysis these 32 parameters are divided into 7 categories. They are:

1. Deposits: consisting of total deposits, current deposits, savings bank deposits, CASA deposits.

2. Funds: consisting of advances, investments, working funds, and average working funds.

3. Expenses: consisting of total expenses, interest expenses, staff expenses, other expenses.

4. Income and Profit: consists of total income, interest income, other income, provisions and contingencies, gross profit, net profit

5. Assets: consists of gross NPA, Net NPA, return on assets, return on average assets.

6. Business parameters: consists of net profit per branch, gross profit per branch, business per branch, business per employee, net profit per employee, gross profit per employee.

7. Ratios: consists of spread to average working fund, expenses to average working, other expenses to average working fund, capital to risk weighted ratio.

\section{Deposits:}

Deposits are the most impartment parameters indicating the customer confidence and trust worthiness of a bank. Table 1 presents the growth of deposits which includes total deposits, current deposits, savings bank deposits, CASA deposits and their annualized compound growth rates for the period 2002 to 2012. The trend curves of different types of deposits are shown in figure 1. 
Table 1: ICICI Bank Deposits during 2002-12 and their Annual Compound Growth Rates

\begin{tabular}{|c|c|c|c|c|c|c|c|c|c|}
\hline \multirow[t]{2}{*}{ Year } & \multicolumn{2}{|c|}{ Deposits } & \multicolumn{2}{|c|}{ Current Deposits } & \multicolumn{2}{|c|}{ Savings Bank Deposits } & \multicolumn{2}{|c|}{ CASA Deposits } & \multirow[t]{2}{*}{ CASA \% } \\
\hline & Total & CGR & Total & CGR & Total & CGR & Total & CGR & \\
\hline 2002 & 32085.11 & 95.9012 & 2736.15 & 4.359119 & 3793.21 & 51.91069 & 6529.36 & 27.55496 & 20.35013 \\
\hline 2003 & 48169.31 & 50.1298 & 3689.45 & 34.84093 & 3793.21 & 0 & 7482.66 & 14.60021 & 15.53408 \\
\hline 2004 & 68109 & 41.39501 & 7259.06 & 96.75182 & 8372.03 & 120.711 & 15631.09 & 108.8975 & 22.95011 \\
\hline 2005 & 99819 & 46.55772 & 12836.9 & 76.8397 & 11391.82 & 36.06999 & 24228.72 & 55.00339 & 24.27265 \\
\hline 2006 & 165083.2 & 65.38251 & 16573.48 & 29.10812 & 20936.98 & 83.7896 & 37510.46 & 54.81817 & 22.72216 \\
\hline 2007 & 230510 & 39.63265 & 21375.65 & 28.97503 & 28838.79 & 37.74093 & 50214.44 & 33.86783 & 21.78406 \\
\hline 2008 & 244431 & 6.039217 & 24691 & 15.50994 & 39089 & 35.54313 & 63780 & 27.01526 & 26.09325 \\
\hline 2009 & 218348 & -10.6709 & 21632 & -12.3891 & 41036 & 4.980941 & 62668 & -1.74349 & 28.70097 \\
\hline 2010 & 202017 & -7.47934 & 30997 & 43.29234 & 53218 & 29.68613 & 84215 & 34.38278 & 41.68709 \\
\hline 2011 & 225602 & 11.67476 & 34777 & 12.19473 & 66869 & 25.6511 & 101646 & 20.69821 & 45.05545 \\
\hline 2012 & 255500 & 13.25254 & 34973 & 0.563591 & 76046 & 13.72385 & 111019 & 9.221219 & 43.45166 \\
\hline
\end{tabular}

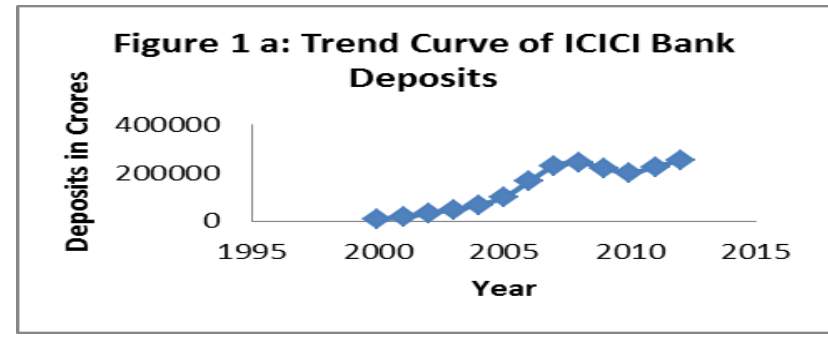

Fig 1 c: Trend Curve of ICICI Bank Savings

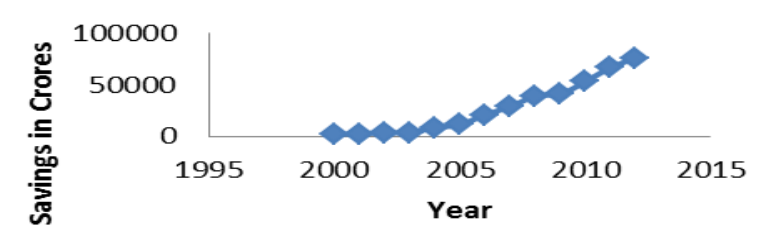

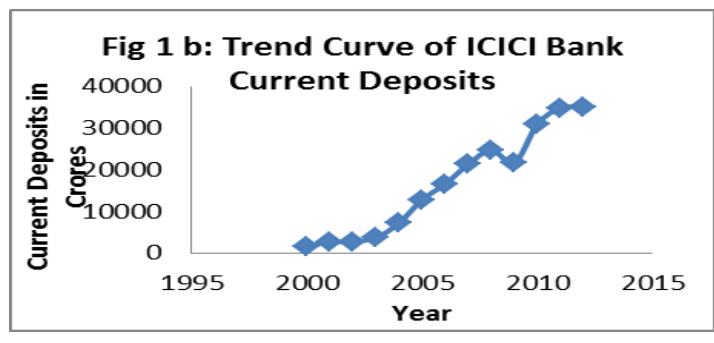

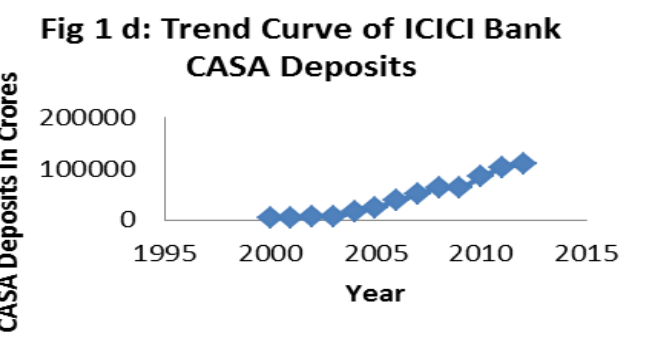

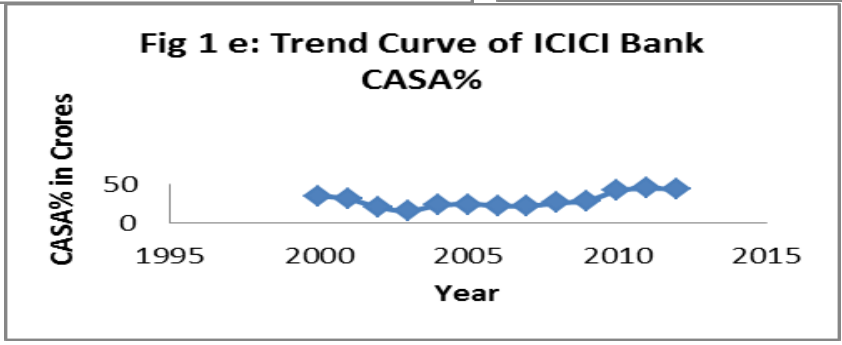

From Table 1 and Figure 1 it is observed that in the year 2002 the total deposits in the ICICI bank is INR 32085.11 crores and it has increased nearly 8 times in 10 years period and became INR 255500 crores in the year 2012. The total deposits have been increased during 2002 to 2008 and there was a decline over the period $2009-10$ and again there is an increasing trend in deposits of the bank. This may be due to the world economic crisis during $2008-10$. The compound growth rate of deposits over the period $2011-12$ is $13.25 \%$. With respect to the current deposits the ICICI bank has increased them from INR 1587.47 crores in 2000 to INR 34973 crores in 2012. The current deposits are having the positive annualized growth rate over all years during 2000 to 2012 except in the year 2008 - 2009, during that period the compound growth rate is $12.39 \%$. The annualized compound growth rate of current deposits during $2011-2012$ is $0.56 \%$. In ICICI bank the savings bank deposits also recorded a positive growth over all years during 2002 to 2012. In all these years the annualized compound growth rate is positive. The savings bank deposits have been increased from INR 1880.64 in 2000 to INR 76046 crores in 2012. The annualized compound growth rate of savings bank deposits during $2011-2012$ was $13.72 \%$. It is to be noted that during the world economic crises period $2008-2010$ there is an increase in the savings bank deposits of ICICI bank. The CASA deposits have also exhibited similar trend of increasing growth over all years from $2000-2012$. However, in the year $2008-09$ there is a decline in CASA deposits with an annual compound growth rate of $-1.7 \%$. This negative growth has been again reverted towards positive in the next year and continuing the positive growth. The CASA percentage is also having a significant increase in the performance of the bank. The CASA percentage has increased from $35.15 \%$ in the year 2000 to 
$43.45 \%$ in 2012 . Over this 12 years period the CASA percentage is low and less than $20 \%$ only during the year $2002-03$.

\section{i. $\quad$ Advances And Funds:}

Table 2 presents the information regarding the advances, investments, working funds and average working funds of ICICI bank during the period 2002 to 2012 and their annualized compound growth rates. Graphs $2 \mathrm{a}, 2 \mathrm{~b}, 2 \mathrm{c}$ and $2 \mathrm{~d}$ show the trend curves of advances, investments, and average working funds respectively.

Table 2: ICICI Bank Advances and Funds during 2002-12 and their Annual Compound Growth Rates

\begin{tabular}{|c|c|c|c|c|c|c|c|c|}
\hline \multirow{2}{*}{ Year } & \multicolumn{2}{|c|}{ Advances } & \multicolumn{2}{c|}{ Investments } & \multicolumn{2}{c|}{ Working Funds } & \multicolumn{2}{c|}{ Average Working Funds } \\
\cline { 2 - 8 } & Total & CGR & Total & CGR & Total & CGR & Total & CGR \\
\hline 2002 & 47034.87 & 568.9204 & 35891.08 & 338.3986 & 105433.3 & 402.8684 & 63199.87 & 273.9587 \\
\hline 2003 & 53279.41 & 13.27641 & 35462.3 & -1.19467 & 106812 & 1.307575 & 106122.7 & 67.91594 \\
\hline 2004 & 62095.51 & 16.54692 & 42742.87 & 20.53045 & 125228.9 & 17.24237 & 116020.4 & 9.326722 \\
\hline 2005 & 91405.15 & 47.2009 & 50487.35 & 18.11876 & 167659.4 & 33.88239 & 146444.1 & 26.22273 \\
\hline 2006 & 146163.1 & 59.90687 & 71547.39 & 41.7135 & 251389 & 49.94026 & 209524.2 & 43.07447 \\
\hline 2007 & 195866 & 34.00509 & 91258 & 27.54903 & 344658.1 & 37.10154 & 298023.5 & 42.23825 \\
\hline 2008 & 225616 & 15.18896 & 105116 & 15.18552 & 399795.1 & 15.99758 & 372226.6 & 24.89839 \\
\hline 2009 & 218311 & -3.2378 & 103058 & -1.95784 & 379301 & -5.12616 & 389548 & 4.653462 \\
\hline 2010 & 181206 & -16.9964 & 120893 & 17.30579 & 363400 & -4.19217 & 371350.5 & -4.67145 \\
\hline 2011 & 216366 & 19.40333 & 134686 & 11.40926 & 406234 & 11.78701 & 384817 & 3.626364 \\
\hline 2012 & 253728 & 17.26796 & 159560 & 18.46814 & 473647 & 16.59462 & 439940.5 & 14.3246 \\
\hline
\end{tabular}
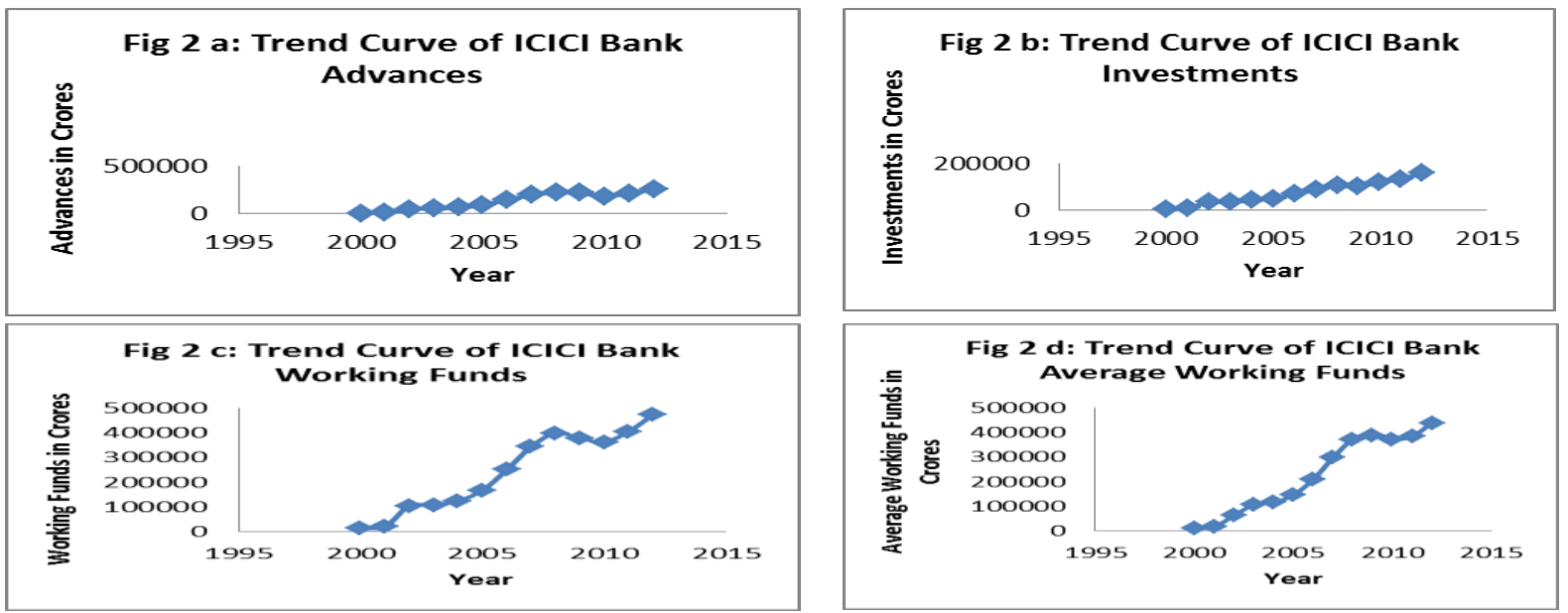

From Table 2 and Figures from $2 \mathrm{a}$ to $2 \mathrm{~d}$, it is observed that the advances in ICICI bank have increased from Rs. 47034.87 crores in 2002 to Rs. 253729 crores in 2012. There is a steady increase in the advances over all years except the years 2009 and 2010. During these years the advances in ICICI bank have declined and recorded a negative annual compound growth rate of $-3.2378 \%$ and $-16.9964 \%$ for the years 2009 and 2010 respectively. However, the advances in the bank have again increased from 2011 onwards and the annual compound growth rate of advances in 2012 is $17.2679 \%$. The investments in the banks have already increased from Rs. 35891.08 crores in 2002 to Rs. 159560 crores in 2012. During the years 2003 and 2009 the investments in the bank have recorded negative annual compound growth rates. Remaining all years there is a steady increase in the investments. In the year 2012 the annual compound growth rate of investments in the bank is $18.46 \%$. Similar trend has been shown by the working funds of the bank. The available working funds of the bank in the year 2002 were Rs. 105433.3 crores. They have increased to Rs. 473647 crores in 2012. Over all years there is a steady increase in the working funds except in the years 2009 and 2010. In those two years the annual compound growth rates of working funds in the bank are $-5.12 \%$ and $-4.19 \%$ respectively.

However, these working funds again increased from the year 2011 onwards. In the year 2012 the annual compound growth rate of the working funds in the bank is $16.59 \%$. The average working fund is the important parameter in the banking performance. The average working fund in the bank is also increased from Rs. 63199.87 crores in the year 2002 to Rs. 439940.5 in the year 2012. In the year 2010 it recorded a negative annual compound growth rate of $-4.67 \%$. In the year 2012 it again became $14.32 \%$. Over the decade the year 2002 has recorded highest annual compound growth rate in advances, investments, working funds and average 
working fund. Even though there is a slump in funds of the bank during 2008-10 it again recovered and moving towards positive growth.

\section{ii. Expenses:}

The banking performance is also influenced by the expenses incurred in its operation. The expenses can be primarily considered into 3 components. Namely, (1) Interest Expenses (2) Staff Expenses and (3) Other Expenses. The sum of all these three expenses is known as total expenses. In addition to these 4 parameters another component usually considered is provisions and contingencies. Hence, to study the performance of ICICI bank the information on the expenses incurred during 2002 to 2012 and their annualized compound growth rates are collected and presented in Table 3. Figures $3 \mathrm{a}$ to $3 \mathrm{~d}$ show the trend curves of total expenses, interest expenses, staff expenses, other expenses and provisions \& contingencies respectively.

Table 3: ICICI Bank Expenses during 2000-12 and their Annual Compound Growth Rates

\begin{tabular}{|c|c|c|c|c|c|c|c|c|c|c|}
\hline \multirow[t]{2}{*}{ Year } & \multicolumn{2}{|c|}{ Total Expenses } & \multicolumn{2}{|c|}{ Interest Expenses } & \multicolumn{2}{|c|}{ Staff Expenses } & \multicolumn{2}{|c|}{ Other Expenses } & \multicolumn{2}{|c|}{$\begin{array}{l}\text { Provisions \& } \\
\text { Contingencies }\end{array}$} \\
\hline & Total & CGR & Total & CGR & Total & CGR & Total & CGR & Total & CGR \\
\hline 2000 & 941.63 & 65.27653 & 788.32 & 61.9525 & 36.37 & 99.94502 & 116.94 & 80.51868 & 121.37 & 98.09042 \\
\hline 2001 & 1301.37 & 38.20397 & 966.74 & 22.63294 & 51.71 & 42.17762 & 282.92 & 141.936 & 129.08 & 6.352476 \\
\hline 2002 & 2468.29 & 89.66858 & 1845.71 & 90.92103 & 147.18 & 184.6258 & 475.4 & 68.03337 & 286.79 & 122.18 \\
\hline 2003 & 9955.69 & 303.3436 & 7944 & 330.4035 & 403.02 & 173.828 & 1608.67 & 238.3824 & 1365.01 & 375.9615 \\
\hline 2004 & 9586.48 & -3.70853 & 7015.25 & -11.6912 & 546.06 & 35.49204 & 2025.17 & 25.89095 & 843.73 & -38.1887 \\
\hline 2005 & 9870.04 & 2.957916 & 6570.9 & -6.33406 & 737.41 & 35.04194 & 2561.73 & 26.49457 & 950.8 & 12.69008 \\
\hline 2006 & 14598.6 & 47.90822 & 9597.45 & 46.0599 & 1082.29 & 46.7691 & 3918.86 & 52.97709 & 1348.34 & 41.81111 \\
\hline 2007 & 23049.06 & 57.88541 & 16358.5 & 70.44632 & 1616.75 & 49.38233 & 5073.81 & 29.47158 & 2764.18 & 105.0062 \\
\hline 2008 & 31638.42 & 37.26555 & 23484.24 & 43.55986 & 2078.9 & 28.58512 & 6075.28 & 19.73803 & 3802.95 & 37.57968 \\
\hline 2009 & 29771.04 & -5.90225 & 22725.93 & -3.22902 & 1971.7 & -5.15657 & 5073.41 & -16.4909 & 5167.09 & 35.87057 \\
\hline 2010 & 23452.4 & -21.2241 & 17592.57 & -22.5881 & 1925.79 & -2.32845 & 3934.04 & -22.4577 & 5707.2 & 10.45289 \\
\hline 2011 & 23574 & 0.518497 & 16957 & -3.61272 & 2817 & 46.27763 & 3800 & -3.40718 & 3896 & -31.7354 \\
\hline 2012 & 30499 & 29.37558 & 22809 & 34.51082 & 3515 & 24.77813 & 4175 & 9.868421 & 4082 & 4.77412 \\
\hline
\end{tabular}
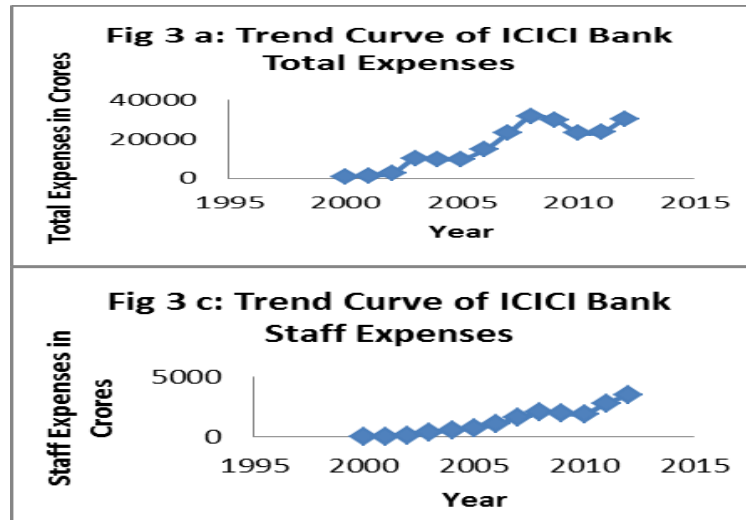
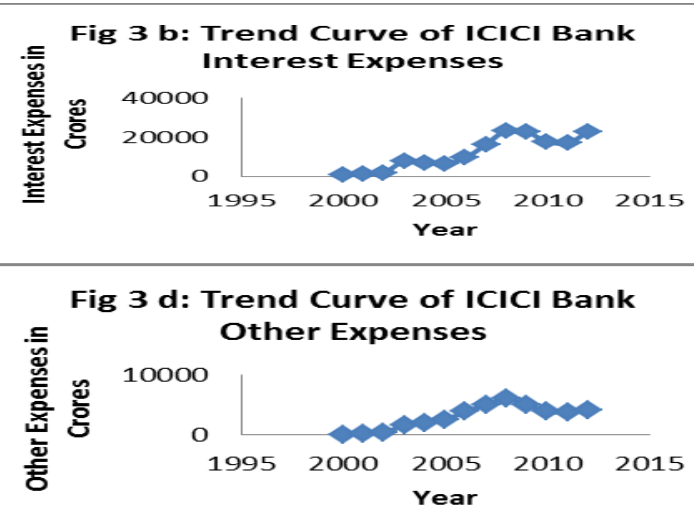

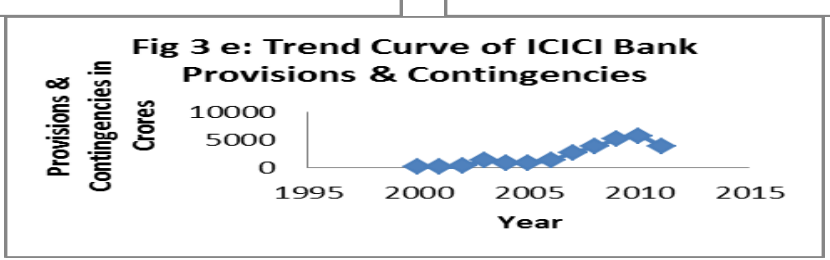

From Table 3 and Figures 3a to 3e reveal that the total expenses in the bank have increased from Rs. 941.63 crores in 2002 to Rs. 30499 crores in 2012. The trend of total expenses had increased during 2000 to 2003 and there was a decreasing in the year 2004 and again the total expenses were increased during the period 2004 to 2008. It also declined in the year 2008. They have recorded an increasing trend with a compound growth rate of $29.3 \%$ in the year 2012. In all these years the total expenses are having major contribution from interest expenses. The interest expenses are also increasing from Rs. 788.32 crores in 2002 to Rs. 22809 crores in 2012. The interest expenses are having negative compound growth rates during the years 2004, 2005, 2009, 2010 and 2011. Rest all the years the compound growth rates of interest expenses are positive. In the year 2012 the compound growth rate of the interest expenses in the bank is $34.51 \%$. Staff expenses are the expenditure incurred for manpower in the bank. The staff expenses are increasing from Rs. 36.37 crores in 2000 to Rs. 3515 crores in 2012. The staff expenses were having negative growth during the years 2009 and 2010. In all the other 
years during the period 2000 - 2012 the staff expenses were having a positive annualized compound growth rates. The staff expenses in the year 2012 were $24.77 \%$.

Other expenses (the expenses other than interest expenses and staff expenses are known as other expenses) are increasing from Rs. 116.94 crores in 2002 to Rs. 4175 crores in 2012. The other expenses in the bank are having positive compound growth rates over all years during 2000 and 2012 except in the years 2009, 2010 and 2011. In the year 2012 the annual growth rate of other expenses was 9.86\%. The provisions and contingencies in the bank is also an important parameter for financial stability of the bank. In ICICI bank the provisions and contingencies are having increasing trend over all years during 2000 to 2010 except in the years 2004 and 2011. During these periods the annualized growth rates of provisions and contingencies were-38.18\% and $-31.73 \%$ respectively. The annualized provisions and contingencies increased from Rs. 121.37 crores in 2000 to Rs. 4082 crores in 2012. The annualized compound growth rate of provisions and contingencies was $4.77 \%$ in the year 2012.

\section{iii. Income and Profits:}

The income and profits are the most important financial parameters for measuring performance of any commercial bank. The five components namely, interest income, other income, total income, gross profit and net profit play a major role in the efficiency and rating of a bank. Accordingly the income and profit in the ICICI bank during 2000 to 2012 with their annualized compound growth rates are collected and presented in Table 4. The trend curves of total income, interest income, other income and net profit are shown in Figures $4 \mathrm{a}$, $4,4 \mathrm{c}, 4 \mathrm{~d}$ and $4 \mathrm{e}$ respectively.

Table 4: ICICI Bank Income and Profits during 2000-12 and their Annual Compound Growth Rates

\begin{tabular}{|c|c|c|c|c|c|c|c|c|c|c|}
\hline \multirow{2}{*}{ Year } & \multicolumn{2}{|c|}{ Total Income } & \multicolumn{2}{c|}{ Interest Income } & \multicolumn{2}{c|}{ Other Income } & \multicolumn{2}{c|}{ Gross Profit } & \multicolumn{2}{c|}{ NET Profit } \\
\cline { 2 - 11 } & Total & CGR & Total & CGR & Total & CGR & Total & CGR & Total & CGR \\
\hline 2000 & 1046.92 & 65.36669 & 852.87 & 56.76028 & 194.05 & 117.9602 & 226.67 & 81.87435 & 105.3 & 66.19318 \\
\hline 2001 & 1462.47 & 39.69262 & 1242.13 & 45.64119 & 220.34 & 13.54805 & 290.18 & 28.01871 & 161.1 & 52.99145 \\
\hline 2002 & 2726.59 & 86.43733 & 2151.93 & 73.24515 & 574.66 & 160.806 & 545.09 & 87.84548 & 258.3 & 60.3352 \\
\hline 2003 & 12526.88 & 359.4339 & 9368.06 & 335.3329 & 3158.82 & 449.685 & 2571.19 & 371.7001 & 1206.18 & 366.9686 \\
\hline 2004 & 11958.98 & -4.53345 & 8894.06 & -5.05975 & 3064.92 & -2.97263 & 2480.83 & -3.51433 & 1637.1 & 35.72601 \\
\hline 2005 & 12826.05 & 7.250368 & 9409.9 & 5.799826 & 3416.15 & 11.45968 & 2956 & 19.15367 & 2005.2 & 22.48488 \\
\hline 2006 & 18487.01 & 44.13643 & 14306.13 & 52.03275 & 4180.88 & 22.38573 & 3888.41 & 31.54296 & 2540.07 & 26.67415 \\
\hline 2007 & 28923.46 & 56.45288 & 22994.29 & 60.73033 & 5929.17 & 41.81632 & 5874.4 & 51.0746 & 3110.22 & 22.44623 \\
\hline 2008 & 39599.11 & 36.91 & 30788.34 & 33.89559 & 8810.76 & 48.60023 & 7960.68 & 35.51478 & 4157.73 & 33.67961 \\
\hline 2009 & 38696.28 & -2.27992 & 31092.55 & 0.988069 & 7603.73 & -13.6995 & 8925.23 & 12.11643 & 3758.13 & -9.61101 \\
\hline 2010 & 33184.58 & -14.2435 & 25706.93 & -17.3213 & 7477.65 & -1.65813 & 9732.18 & 9.041224 & 4024.98 & 7.100606 \\
\hline 2011 & 32622 & -1.69531 & 25974 & 1.038903 & 6648 & -11.0951 & 9048 & -7.03008 & 5151 & 27.97579 \\
\hline 2012 & 41046 & 25.82306 & 33543 & 29.14068 & 7503 & 12.86101 & 10547 & 16.5672 & 6465 & 25.50961 \\
\hline
\end{tabular}

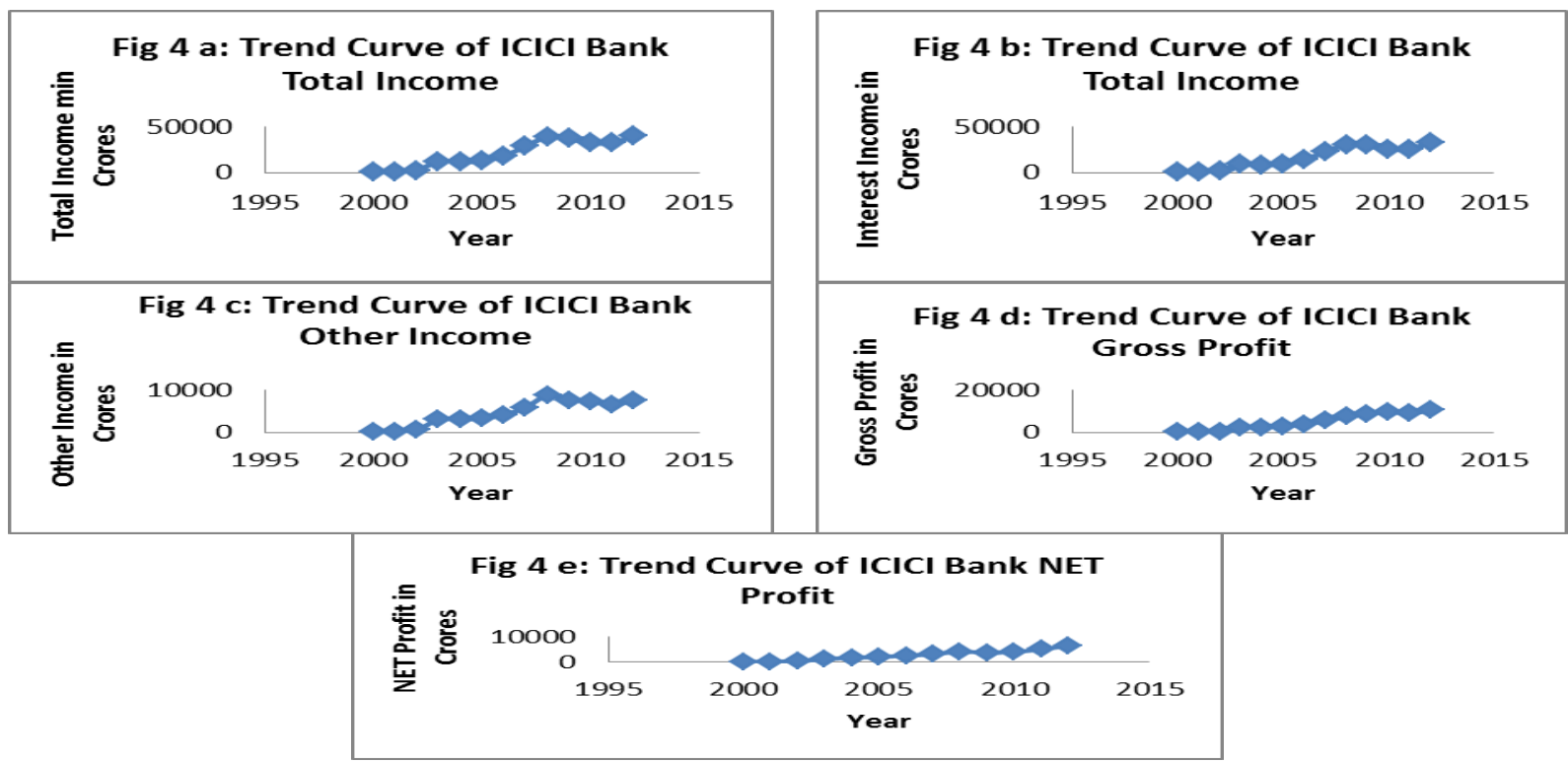

From Table 4 and Figures $4 \mathrm{a}$ to $4 \mathrm{e}$ it is observed that the total income in the bank has increased from Rs. 1046.92 crores in 2000 to Rs. 41046 crores in 2012. The total income in the bank has recorded positive annualized growth rates during the years $2000-2003,2005$ - 2008 and 2012. In the remaining years the 
annualized growth rates of total income in the bank were negative. The annualized compound growth rate of total income in the bank for the year 2012 was $25.82 \%$. The interest income in the bank is also increasing from Rs. 852.87 crores in 2000 to Rs. 33543 crores in 2012 respectively. The annualized compound growth rates of interest income in the bank were positive for all the years during 2000 - 2012 except the years 2004 and 2010. During these two years they were $-5.05 \%$ and $-17.32 \%$ respectively. In the year 2012 the annualized compound growth rate of interest income in the bank was 29.14\%. The growth recorded in the years 2011 and 2012 show the bank was getting more interest income even during global economic crisis period. Other income is the income generated in the bank other than interest income. The other income has increased from Rs. 194.05 crores in 2000 to Rs. 7503 crores in 2012. The other income had recorded negative annual compound growth rates in the years 2004, 2009, 2010, 2011. In all the remaining years it was positive. The annual compound growth rate of other income in the year 2012 was $12.86 \%$.

Profit is one of the most important parameters for measuring the efficiency of the bank. The gross profit in the bank had increased from Rs. 226.67 crores in 2000 to Rs. 10547 crores in 2012. The annualized compound growth rate of gross profit in the year 2012 was $16.56 \%$. The net profit also increased in the bank from Rs. 105.3 crores in 2000 to Rs. 6465 crores in 2012. This growth was very high. The annualized compound growth rate of net profit in the bank is positive in all the years except in the year 2009. The compound growth rate of net profit in the year 2012 was $25.51 \%$. The increasing trends of the gross profit and net profit indicate that the bank is performing efficiently and effectively in all the years. Even though there is world economic crisis in the year 2009, the bank has recorded a net profit of Rs. 3758.13 crores.

\section{iv. Assets:}

Assets are another important financial factor of the growth and stability of any commercial bank. The parameters with respect to assets in a bank can be classified in to two categories. They are : 1) nonperforming assets and 2) revenue generating assets. The performance of these assets can be measured through return on assets, return on average assets, gross NPA and net NPA. Table 5 shows the growth of these 4 parameters over the years 2000 to 2012 and their compound growth rates. Figures 5a, 5b, 5c, and 5d show the growth curves of return on assets, average return on assets, gross NPA, and net NPA.

Table 5: ICICI Bank Assets during 2000-12 and their Annual Compound Growth Rates

\begin{tabular}{|c|c|c|c|c|c|c|}
\hline \multirow[t]{2}{*}{ Year } & \multirow{2}{*}{$\begin{array}{c}\text { Return on } \\
\text { Assets }\end{array}$} & \multirow{2}{*}{ 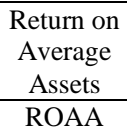 } & \multicolumn{2}{|c|}{ Gross NPA } & \multicolumn{2}{|c|}{ NET NPA } \\
\hline & & & Total & CGR & Total & CGR \\
\hline 2000 & 0.87 & 1.039785 & 94.61 & & 55.92 & \\
\hline 2001 & 0.82 & 0.953242 & 409.25 & 332.5653 & NA & \\
\hline 2002 & 0.67 & 0.408703 & 5013.03 & 1124.931 & NA & \\
\hline 2003 & 1.13 & 1.136591 & 5027.38 & 0.286254 & 2823.77 & \\
\hline 2004 & 1.411045 & 1.411045 & 3047.6 & -39.38 & 1372.4 & -51.3983 \\
\hline 2005 & 1.369259 & 1.369259 & 2770.43 & -9.0947 & 1505.27 & 9.68158 \\
\hline 2006 & 1.212304 & 1.212304 & 2273 & -17.955 & 1075 & -28.5842 \\
\hline 2007 & 1.043616 & 1.043616 & 4168 & 83.37 & 2019 & 87.81395 \\
\hline 2008 & 1.039965 & 1.116989 & 7579.54 & 81.85077 & 3490.55 & 72.88509 \\
\hline 2009 & 0.990804 & 0.964741 & 9649.31 & 27.30733 & 4553.94 & 30.46483 \\
\hline 2010 & 1.107589 & 1.083876 & 9480.65 & -1.7479 & 3841.11 & -15.653 \\
\hline 2011 & 1.267988 & 1.338558 & 10034 & 5.836625 & 2407 & -37.3358 \\
\hline 2012 & 1.364941 & 1.469517 & 9475 & -5.57106 & 1861 & -22.6838 \\
\hline
\end{tabular}

From Table 5 and Figures from $5 \mathrm{a}$ to $5 \mathrm{~d}$ it is observed that the return on assets and average return on assets are having increasing trend during the period 2003 to 2012 except in the year 2009. The return on assets increased from 1.13 in 2003 to 1.36 in 2012.Similarly the return on average assets also increased from 1.13 in 2003 to 1.47 in 2012. But in the year 2009 both ROA and ROAA are 0.99 and 0.96 respectively. The net NPA also increased from Rs. 5027.38 crores in 2003 to Rs. 9475 crores in 2012 . Even though there was an increase in 2011-12, the gross net NPA had recorded negative annualized compound growth rate of $-5.57 \%$. However, in the bank the net non performing assets have declined from Rs. 2823.77 crores in 2003 to Rs. 1861 crores in 2012. The annualized compound growth rate during the period 2011-12 was $-22.68 \%$. This negative growth indicates the bank is taking appropriate measures to reduce the liability due to non performing assets and to increase the return on assets. 

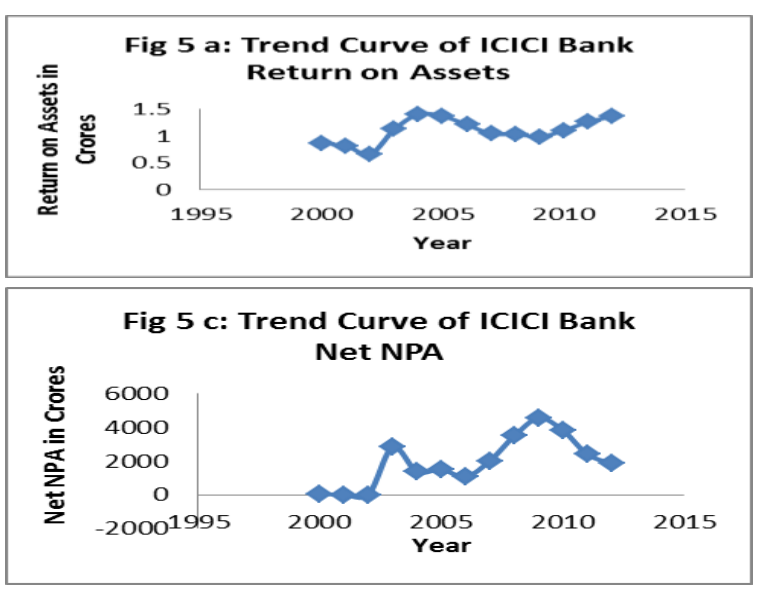
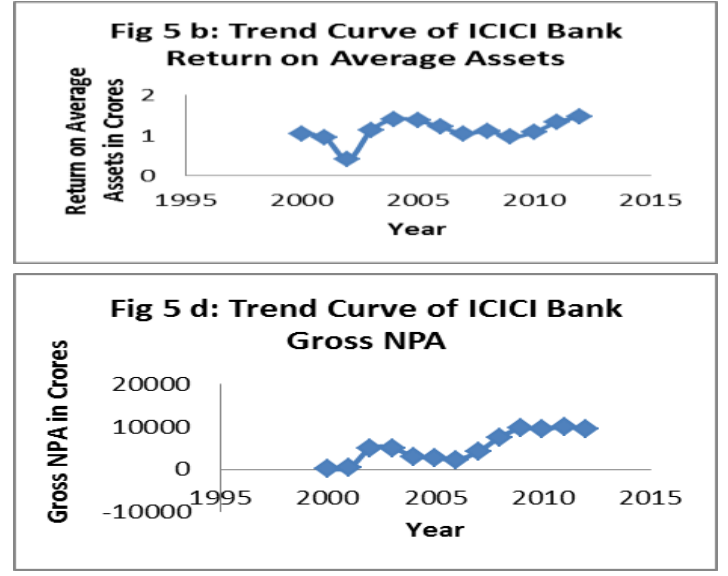

\section{v. Business Performance Parameters:}

The operational performance of the bank is evaluated through the growth of the business parameters such as total business, business per employee, business per branch, net profit per employee, gross profit per employee, net profit per branch. Hence, the data on these parameters over the periods 2000 to 2012 is collected and presented in Table 6, Figures $6 \mathrm{a}, 6 \mathrm{~b}, 6 \mathrm{c}, 6 \mathrm{~d}, 6 \mathrm{e}$, and $6 \mathrm{f}$ represent the growth curves of total business per employee, net profit per branch and gross profit per branch respectively.

TABLE 6: ICICI Bank Business Performance Parameters during 2000-12 and their Annual Compound Growth

\begin{tabular}{|c|c|c|c|c|c|c|c|c|}
\hline \multicolumn{9}{|c|}{ Rates } \\
\hline \multirow[t]{2}{*}{ Year } & \multicolumn{2}{|c|}{ Total Business } & \multirow{2}{*}{$\begin{array}{c}\text { Business } \\
\text { per } \\
\text { Employee }\end{array}$} & \multirow{2}{*}{$\begin{array}{c}\text { Business } \\
\text { per Branch }\end{array}$} & \multirow{2}{*}{$\begin{array}{l}\text { Net Profit } \\
\text { per } \\
\text { Employee }\end{array}$} & \multirow{2}{*}{$\begin{array}{c}\text { Gross Profit } \\
\text { per } \\
\text { Employee }\end{array}$} & \multirow{2}{*}{$\begin{array}{l}\text { Gross Profit } \\
\text { per Branch }\end{array}$} & \multirow{2}{*}{$\begin{array}{c}\text { Net Profit } \\
\text { per } \\
\text { Branch }\end{array}$} \\
\hline & Total & CGR & & & & & & \\
\hline 2000 & 13523.39 & 65.26079 & 1006.205 & 166.9554 & 7.834821 & 16.86533 & 2.798395 & 1.3 \\
\hline 2001 & 23409.67 & 73.10504 & 850.9513 & 65.94273 & 5.856052 & 10.54816 & 0.817408 & 0.453803 \\
\hline 2002 & 79119.98 & 237.9799 & 2114.377 & 221.0055 & 6.902726 & 14.56681 & 1.522598 & 0.721508 \\
\hline 2003 & 101448.7 & 28.22137 & 2711.083 & 227.4635 & 32.23356 & 68.71165 & 5.765 & 2.704439 \\
\hline 2004 & 130204.5 & 28.34515 & 956.753 & 310.7506 & 12.02954 & 18.22933 & 5.920835 & 3.90716 \\
\hline 2005 & 191224.2 & 46.86446 & -1.25198 & 340.2565 & 11.04124 & 16.27664 & 5.259786 & 3.567972 \\
\hline 2006 & 311246.3 & 62.76515 & 1052.938 & 506.9158 & 10.00658 & 15.31835 & 6.332915 & 4.136922 \\
\hline 2007 & 426376 & 36.98991 & 1226.151 & 564.7364 & 9.334114 & 17.62972 & 7.780662 & 4.119497 \\
\hline 2008 & 470047 & 10.24237 & 1279.601 & 372.462 & 10.21907 & 19.56614 & 6.307987 & 3.294556 \\
\hline 2009 & 436659 & -7.10312 & 1155.304 & 307.723 & 10.8629 & 25.79844 & 6.289803 & 2.648436 \\
\hline 2010 & 383223 & -12.2375 & 1262.166 & 224.5009 & 11.41644 & 27.60432 & 5.701336 & 2.357926 \\
\hline 2011 & 441968 & 15.32919 & 1086.972 & 174.76 & 9.04176 & 15.88232 & 3.577699 & 2.036773 \\
\hline 2012 & 509228 & 15.2183 & 775.8044 & 185.0392 & 11.34828 & 18.51358 & 3.832485 & 2.349201 \\
\hline
\end{tabular}
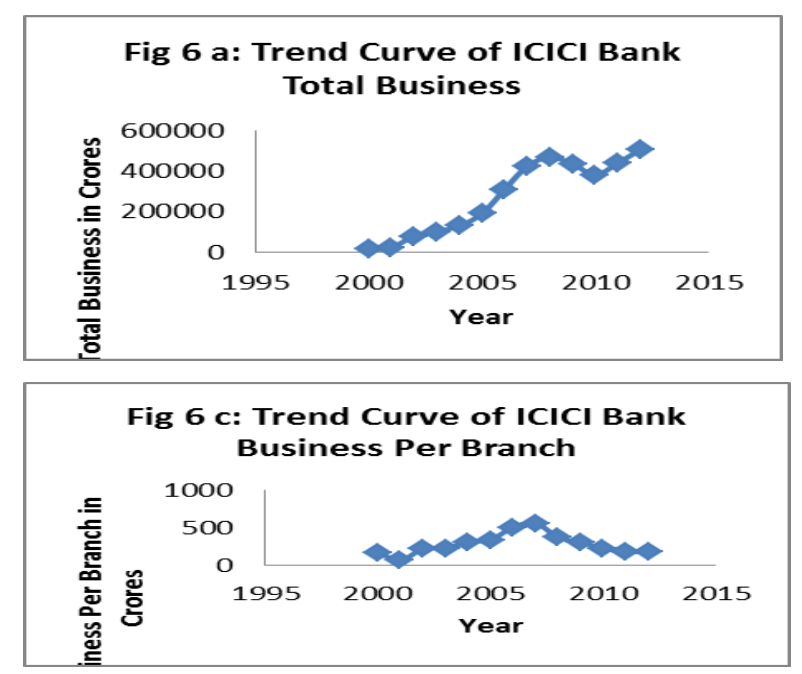
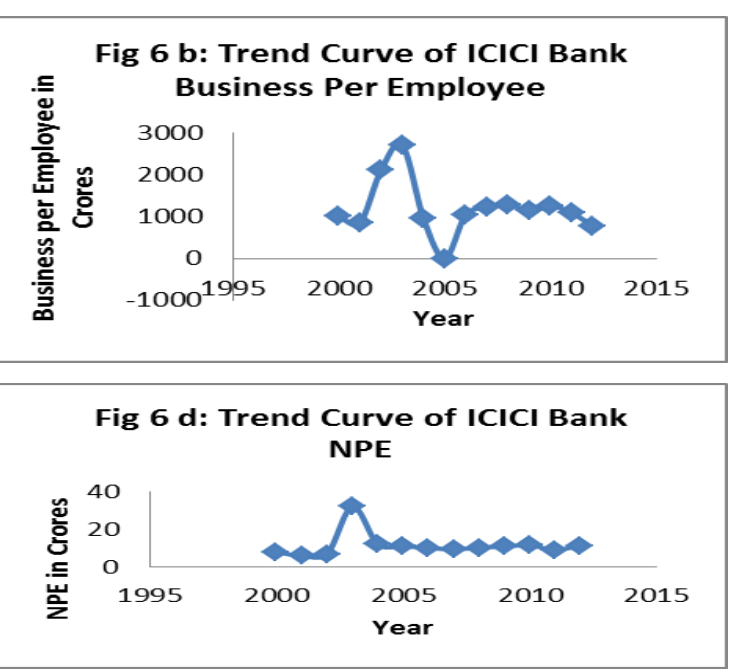

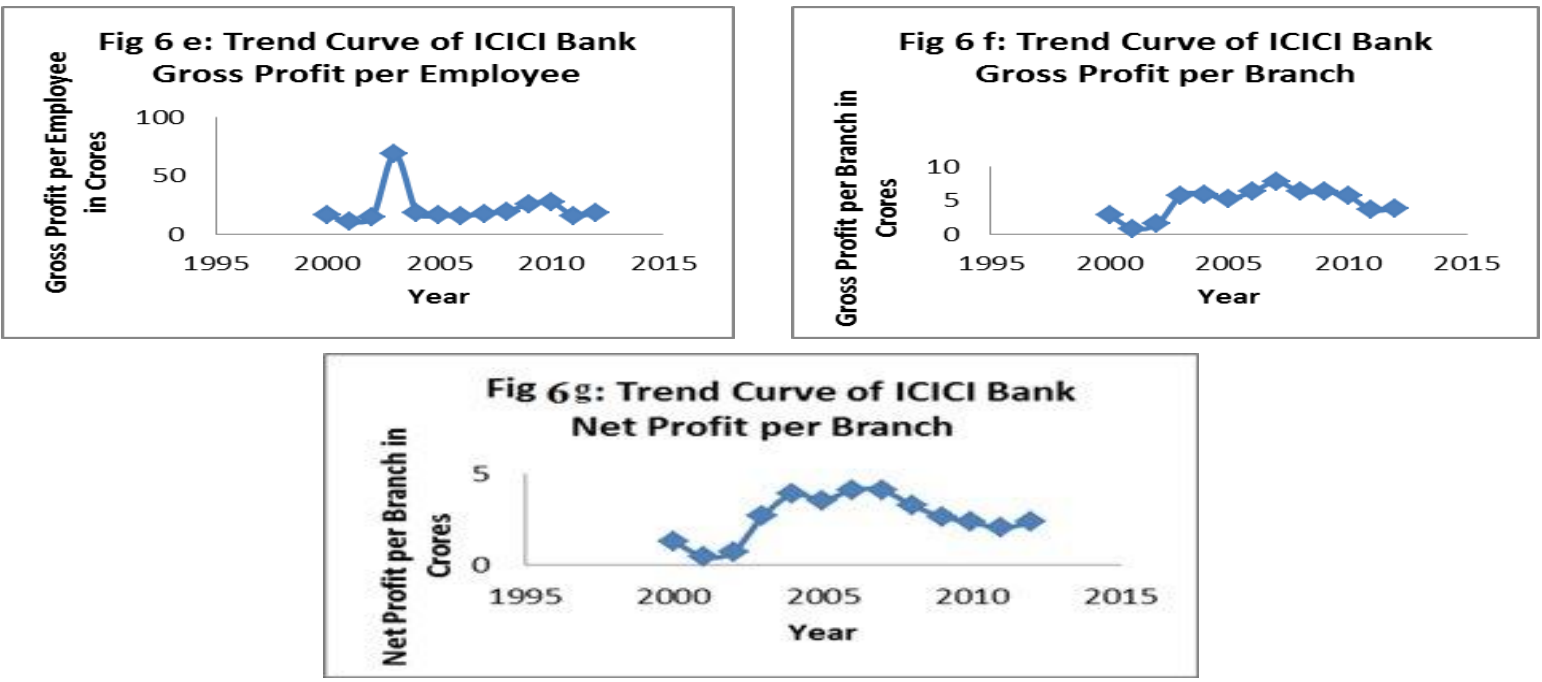

From Table 6 and Figures 6a to $6 \mathrm{f}$ it is observed that all parameters related to the business are increasing. The total business in the bank increased from Rs. 13523.39 crores in 2000 to Rs. 5092288 Crores in 2012. There is a steady growth in total business over the years 2000 to 2008 with positive annual growth rates. But during the periods 2008-09 and 2009-10 the total business declined with negative compound growth rates. This may be due to the influence of global economic recession during 2008-10. However, during the periods 2010-11 and 2011-12, there was increasing trend in total business with positive annualized growth compound rates $15.32 \%$ and $15.22 \%$ respectively.

The net profit per employee in the bank the bank increased from 7.8 in 2000 to 11.34 in 2012. This was maximum in the year 2003 with 32.23. The gross profit per employee also increased from 1.3 in 2000 to 2.34 in 2012. This was maximum in the year 2006 with 4.13. The net profit per branch in the bank also increased from 16.86 in the year 2000 to 18.51 in the year 2012. This was maximum in the year 2003 with 68.71 . The gross profit per branch increased from 2.79 in 2000 to 3.83 in 2012. This was maximum in the year 2000 with 7.78.

\section{vi. Performance Ratios:}

In commercial banks the performance ratios play a dominant role with respect to the development of the bank. The major ratios usually considered are (1) Ratio of spread to average working fund. (2) Ratio of establishment expenses to average working funds. (3) Other working expenses to average working fund. (4) Ratio of non interest to total income. (5) Ratio of gross profit to average working fund and (6) Capital to risk weighted assets ratio. Table 7 shows the growth of these ratios over 2000 to 2012 in the ICICI bank. The trend curves in the ratio are shown in Figures $7 \mathrm{a}$ to $7 \mathrm{f}$.

TABLE 7: ICICI Bank Performance Ratios during 2000-12 and their Annual Compound Growth Rates

\begin{tabular}{|c|c|c|c|c|c|c|}
\hline Year & $\begin{array}{c}\text { Ratios of } \\
\text { Spread } \\
\text { /Average } \\
\text { Working Fund }\end{array}$ & $\begin{array}{c}\text { Establishment } \\
\text { Expenses/Average } \\
\text { Working Fund }\end{array}$ & $\begin{array}{c}\text { Other } \\
\text { Expenses } \\
\text { /Average } \\
\text { Working Fund }\end{array}$ & $\begin{array}{l}\text { Non-Interest } \\
\text { Income/ } \\
\text { Total Income }\end{array}$ & $\begin{array}{c}\text { Gross } \\
\text { Profit/Average } \\
\text { Working Fund }\end{array}$ & $\begin{array}{c}\text { Capital to Risk } \\
\text { Weighted } \\
\text { Assets Ratio }\end{array}$ \\
\hline 2000 & 1.54 & 3.86 & 2.35 & 18.54 & 2.35 & 19.64 \\
\hline 2001 & 2.05 & 3.97 & 2.14 & 15.07 & 2.14 & 11.57 \\
\hline 2002 & 0.57 & 5.96 & 2.49 & 21.08 & 2.49 & 11.44 \\
\hline 2003 & 1.33 & 3.56 & 2.13827 & 25.21633 & 2.13827 & 11.1 \\
\hline 2004 & 1.59 & 0.470659 & 2.018517 & 25.62861 & 2.018517 & 10.36 \\
\hline 2005 & 1.69 & 0.503544 & 1.855829 & 26.63447 & 1.855829 & 11.78 \\
\hline 2006 & 2.247321 & 0.516547 & 1.97112 & 22.61523 & 1.97112 & 13.35 \\
\hline 2007 & 2.226599 & 0.542491 & 2.138665 & 20.49952 & 2.138665 & 11.69 \\
\hline 2008 & 1.962272 & 0.558504 & 2.291176 & 22.24989 & 2.291176 & 14 \\
\hline 2009 & 2.147776 & 0.506151 & 2.620753 & 19.64977 & 2.620753 & 15.53 \\
\hline 2010 & 2.185095 & 0.518591 & 2.351247 & 22.53351 & 2.351247 & 19.41 \\
\hline 2011 & 2.343192 & 0.732036 & 2.39737 & 20.37889 & 2.39737 & 19.54 \\
\hline 2012 & 2.439875 & 0.798972 & 2.81 & 18.27949 & 2.81 & 18.52 \\
\hline
\end{tabular}



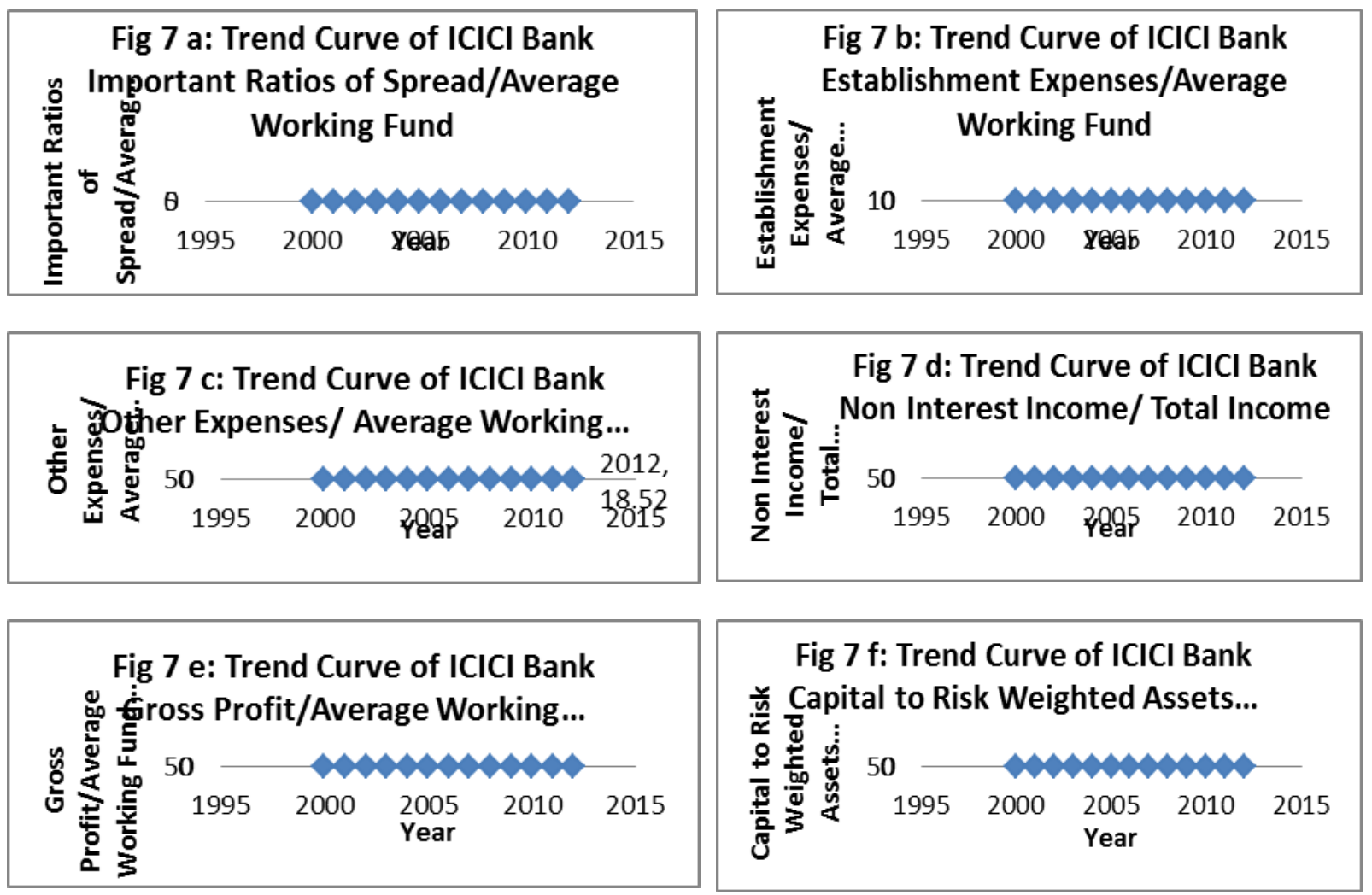

From Table 7 and Figures $7 \mathrm{a}$ to $7 \mathrm{f}$ it is observed that the performance ratios of the bank are having positive increasing growth in the ICICI bank. The ratio of spread against average working fund was increasing from 0.57 in 2002 to 2.4398 in 20012. This ratio increased during 2002 - 07 and declined in the year 2008 . There after it is in increasing trend. With respect to the ratio of establishment expenses to average working fund the value decreased from 5.96 in 2002 to 0.7989 in 20012. This ratio was least in the year 2004 .

During the year 2008 there was a slight increase in this ratio and again declined in the year 2009. From 2010 onwards this ratio is in increasing trend. Another performance ratio of the bank is other expenses to average working fund. This ratio has increased from 2.49 in 2002 to 2.81 in 2012. During the period $2002-05$ this ratio had declined and there after increased up to 2009. Again there was a decline in the year 2010. From 2010 onwards this ratio is in increasing trend. The ratio between noninterest income to total income is having differential growth during the last decade. It increased from 21.08 in 2002 to 26.63 in 2005, there after it declined up to 2007 and increased in the year 2008. There is a declining trend of this ratio from 2010 onwards. In the year 2012 this ratio was 18.27. The important ratio related to the profit of the bank is gross profit to average working fund. This ratio increased from 2.49 in 2002 to 2.81 in 2012. During the last decade this ratio encountered several fluctuations and overall it was above 2 in all the years from 2002 to 2012 . The capital to risk weighted assets ratio increased from 11.44 in 2002 to 8.52 in 2012. During the last decade this ratio was highest of 19.54 in the year 2011. It was least at 10.36 in the year 2004. All the years in the last decade it was above 10. This indicates the bank is having stabile and having good capital base. The overall trends of all these ratios reveal that the bank is performing well with effective growth inspite of some challenges faced during the years 2007-09.

\section{Conclusions}

This paper deals with the knowledge management initiatives adopted during the last decade in a private sector bank namely, ICICI bank and its performance and growth. The knowledge management is basically meant for utilizing the knowledge within the organization through acquiring, storing, and sharing for problem solving strategic planning and integrating with effective decision making. Realizing the importance of Knowledge Management the ICICI bank has started implementing it since 2002. The various strategies of integrating IT and ICT with knowledge acquisition and sharing made the bank to provide a successful story for other commercial banks to follow. They have adopted various, management tools such as developing a KM Portal (Wise Guy) and implementing the other initiatives such as brown bag, wise Wednesdays, corporate learning, dairy dose, developing query boards, organizing seminars, encouraging employees etc,. 
The Knowledge management initiatives in ICICI bank made a tremendous impact on the performance of the bank in various operational parameters such as deposits, current deposits, savings bank deposits, CASA deposits, share of CASA percentage, advances, investments, working funds, total expenses, interest expenses, staff expenses, other expenses, total income, interest income, other income, gross profit, provisions and contingences, net profit, gross NPA, net NPA, staff strength, number of branches, the ratio of non - interest of income to total income, the ratio of spread to average working fund, the ratio of establishment expenses to average working fund, the ratio of other expenses to average working fund, the ratio of gross profit to average working fund, return on assets, return on average assets, total business, business per employee, business per branch, net profit per employee, gross profit per employee, gross profit per branch, net profit per branch. The information on these parameters is analysed through computing annualized compound growth rates and plating the trend curves for the period 2002-2012. These 32 parameters are grouped into seven factors namely, Deposits, Funds, Expenses, Income and Profits, Assets, Business Parameters and Performance Ratios. From the analysis it is observed that the performance parameters have recorded an increasing trend over the period 2002 2012 in spite of several challenges the bank has been encountered due to various factors like global recession, employ iteration. The ICICI bank is one of the few private sector banks which are having sound financial stability during the world economic crisis period 2008-2010.

The implementation of Knowledge management strategy at ICICI bank is providing lot of insights for other commercial banks to deviate from their traditional methods of face to face knowledge sharing and documentation systems. It is a prominent consideration now for all commercial banks to adapt effective and efficient Knowledge management in order to improve a customer satisfaction and to sustain in the present day competitive banking environment.

\section{References}

[1]. Anurag B. Singh, Priyanka Tandon (2012), "A study of financial performance: A comparative analysis of SBI and ICICI Bank", International Journal of Marketing, Financial Services\& Management Research, Vol.1, Issue 11, Pp:56-71.

[2]. Bhogaraju G. (2005), knowledge management: Why do we need IT for Corporates, Malaysian Journal of Library \& Information Science, Vol.10, Issue. 2, Pp: 37-50.

[3]. Chanda Kochhar (2008), "Whenever there's a challenge, I see an Opportunity", ( http://knowledge.wharton.upenn.edu/article/icicischanda-kochhar-whenever-theres-a-challenge-i-see-an-opportunity).

[4]. Chaminda Chiran Jayasundara (2008), "Knowledge Management in Banking Industries: uses and opportunities" Journal of University Librarians Association od Sri Lanka, Vol.12, Pp: 68-84.

[5]. Deepa Prabhu (2006), KM Tigers, Inside Knowledge, Vol.9, Issue .9.

[6]. ICICI Bank, $18^{\text {th }}$ Annual Report and Accounts (2011-12)

[7]. ICICI Bank, 19 $9^{\text {th }}$ Annual Report and Accounts (2012-13).

[8]. ICICI Bank bulletin 2012

[9]. Khalid Alrawi, Sobhy Elkhatib (2009), "Knowledge management practices in the Banking Industry: Present and Future State-Case Study", Journal of Knowledge Management Practice, Vol.10, Issue No.4.

[10]. Rita Yi Man Li (2012), knowledge management, sharing and creation in developing countries banking industries, advanced in Network and Communications (ANC), Vol.1, Issue 1, Pp: 13-26.

[11]. Samir Baruah (2008), "Managing knowledge in banks: An introduction based on Experience", CAB Calling, October-December, Pp: $30-33$.

[12]. Suvarchala M.B. (2013) "Knowledge management in commercial banks-A study of the State Bank of India" International Journal in Multidisciplinary and Academic Research (SSIJMAR), May-June, Vol.2, No.3, Pp: 1-14.

[13]. Sudharani D., Vijay Kumar P, Rama Mohana Rao K (2013), "Studies on growth and performance of Indian Commercial banks during global economic recession (IJCEM), Vol.16, Issue 6, Pp: 39-48.

[14]. Yogeswaran G and Selvaraju V.M (2011), knowledge centric human resource management practices-A comparative study between SBI and ICICI, International Journal of research in Commerce and Management, Vol.2, Issue.9, Pp:.71-81. 